九州大学学術情報リポジトリ

Kyushu University Institutional Repository

\title{
Aboveground productivity of an unsuccessful 140-year-old Cryptomeria japonica plantation in northern Kyushu, Japan
}

Enoki, Tsutomu

Kyushu University Forest, Kyushu University

Inoue, Takafumi

Graduate School of Bioresource and Bioenvironmental Science, Kyushu University

Tashiro, Naoaki

Ashoro Research Forest, Kyushu University

Ishi i, Hiroaki

Department of Plant Sciences, Graduate School of Agricultural Science, Kobe University

http://hdl. handle. net/2324/25618

出版情報：Journal of Forest Research. 16 (4)，pp.268-274, 2011-08-01. Springer Japan バージョン:

権利関係: (C) The Japanese Forest Society and Springer 2010 
Aboveground productivity of an unsuccessful 140-year-old Cryptomeria japonica plantation in

northern Kyushu, Japan

Tsutomu Enoki ${ }^{1}$, Takafumi Inoue ${ }^{2}$, Naoaki Tashiro ${ }^{3}$, Hiroaki Ishii ${ }^{4}$,

${ }^{1}$ Kyushu University Forest, Kyushu University, Sasaguri, Fukuoka 811-2415, Japan

${ }^{2}$ Graduate School of Bioresource and Bioenvironmental Science, Kyushu University, Fukuoka, Japan

${ }^{3}$ Ashoro Research Forest, Kyushu University, Hokkaido, Japan

${ }^{4}$ Department of Plant Sciences, Graduate School of Agricultural Science, Kobe University, Kobe, Japan

Tel. +81-92-948-3111

Fax +81-92-948-3119

E-mail: enoki@forest.kyushu-u.ac.jp

Article type: original paper

Subject areas and fields: Biology and ecology (Silviculture, or Vegetation dynamics)

Page count: $24 \quad$ Number of tables: 4, Number of figures: 3 


\section{Abstract}

We measured the aboveground biomass, biomass increment and litterfall production of a 140-year-old, abandoned Cryptomeria japonica plantation in order to infer the effects of topography on biomass production. The plantation was unsuccessful and the naturally regenerated broad-leaved trees contributed $93.4 \%\left(374.2 \mathrm{Mg} \mathrm{ha}^{-1}\right)$ of the total aboveground biomass $(400.2$ Mg ha ${ }^{-1}$ ). Comparing between different slope positions, aboveground biomass decreased downslope corresponding to the decrease in broad-leaved tree biomass. The biomass of $C$. japonica did not vary with slope position. Biomass increment and litterfall production of the broad-leaved trees also decreased downslope. However, litterfall production per unit biomass and aboveground net primary production per unit biomass increased downslope. Results of a path analysis showed that biomass increment of $C$. japonica decreased with increasing topographical convexity, whereas biomass and litterfall production of broad-leaved tree increased. Litterfall production of broad-leaved tree decreased with increasing biomass of $C$. japonica, suggesting that, despite their small biomass, the presence of residual $C$. japonica may have negative effects on the distribution and productivity of the broad-leaved trees. Our results indicated that total aboveground biomass of the study site was comparable to that of old-growth $C$. japonica plantations. We inferred that the variation in aboveground biomass of the broad-leaved trees was largely determined by the topography, while their productivity was affected by interactions with 
planted C. japonica.

Keywords: biomass, litterfall, mixed forest, unsuccessful plantation, topography 


\section{Introduction}

Old growth forests are usually carbon sinks (Luyssaert et al. 2008), though forest growth declines with stand age (Kira and Shidei 1967; Gower et al. 1996, Ryan et al. 2004). In Japan, the area of mature plantations that have passed harvesting age is increasing, because under the current economic and social situation, timber prices cannot cover the harvesting cost and clearcutting areas have been reduced. As a result, many conifer plantations are shifting to long-rotation forestry, but it is not clear whether the aging plantations will continue to be productive. Some studies indicate that growth is maintained in Cryptomeria japonica D. Don plantations up to 200 years (Takeuchi 2005; Masaki et al. 2006 ; Watanabe and Mogi 2007) and in 84-year-old Chamaecyparis obtusa Sieb. et Zucc plantation (Kondo et al. 2001). Variable results have been reported for age-related changes in litterfall production, which is correlated with stand productivity. Litterfall production decreased with increasing stand age for $C$. japonica, while it did not change for C. obtusa (Inagaki et al. 2004; Ichikawa et al. 2006). In contrast, an increase in litterfall production with stand age has also been reported for C. japonica (Shutou and Nakane 2004).

Because various factors such as stand density, site index, and management influence stand productivity, more data from various old-aged plantations are needed to understand the age-related changes in stand productivity of Japanese plantation forests.

Conifer growth is especially low in heavy snowfall regions (Yokoi and Yamaguchi 2000; 
Masaki et al. 2004) and in high-altitude areas (Sato et al. 1995; Kominami et al. 2004). Plantations in these areas were often unsuccessful and eventually abandoned. In abandoned, unsuccessful conifer plantations, broad-leaved trees often regenerate naturally resulting in a mixed conifer-broadleaf forest (Imada et al. 1991; Hasegawa and Taira 2000; Masaki et al. 2004; Kodani 2006). In natural, mixed conifer-broadleaf forests, stand basal area tends to be greater than that of forests comprising only broadleaved trees (Midgley et al. 2002; Aiba et al. 2007). This suggests that, although the unsuccessful plantations may be unsuitable for timber production, stand productivity may not be low. However, we are aware of no previous studies documenting the primary production of unsuccessful Japanese conifer plantations.

Many conifer plantations in Japan have been established on steep slopes with complicated topography. In the plantations, topographic heterogeneity is a major factor affecting stand dynamics and productivity through its effects on edaphic conditions (Hirobe et al. 1998; Tokuchi et al. 2000; Nishina et al. 2009), tree growth (Tange et al. 1989; Enoki et al. 1996; Kohama et al. 2006; Tsuji et al. 2007) and litterfall production (Enoki et al. 1997). The occurrence of naturally regenerated broad-leaved species also varies depending on topography (Ito et al. 2003, 2006), indicating that topography may also affect the regeneration pattern of the broad-leaved trees, as well as the competition between the planted conifer trees and the naturally regenerated broadleaved trees. In the present study, we estimated the aboveground biomass and aboveground net primary 
production (ANPP) of a 140-year-old, unsuccessful C. japonica plantation to infer the effects of topography on biomass and productivity. We attempted to answer the following questions: 1) Is an abandoned, old-growth plantation more or less productive than managed plantations? 2) How does the topography influence biomass and productivity of the plantation? 3) How do topography and the planted tree influence biomass and productivity of broad-leaved trees?

\section{Methods}

Study site

This study was carried out in Kasuya Research Forest of Kyushu University located in Fukuoka prefecture southwestern Japan $\left(33^{\circ} 39^{\prime} \mathrm{N}, 130^{\circ} 32^{\prime} \mathrm{E}\right)$. The mean annual temperature and precipitation were $16.1^{\circ} \mathrm{C}$ and $1499 \mathrm{~mm}$, respectively in $1999-2003$ (Kasuya Research Forest, Kyushu University). The study site was located on a steep slope (mean inclination $=36.0$ degrees) within an elevation range from 400 to $500 \mathrm{~m}$ asl. The study site is a C. japonica plantation that was established about 140 years ago. No records are available that indicate any silvicultural treatments (e.g., pruning and thinning). The present study site is inferred to be an unsuccessful plantation, in which planted $C$. japonica could not form a closed canopy and broad-leaved trees regenerated naturally (Table 1). Dominant canopy trees include, Quercus saliciana Blume and Carpinus tschonoskii Bl.,on the upper part of the slope, and Swida controversa Sojak and Acer palmatum Thunb on lower part of the slope. 
Camellia japonica L. are dominant in the subcanopy layer. Details of the study site have been reported in Inoue et al. (2008).

Tree census

A $100 \mathrm{~m} \times 100 \mathrm{~m}$ study plot, including a ridge top and a valley bottom, was established on a north-facing slope (Fig.1). The plot was divided into 100 cells, each measuring $10 \mathrm{~m} \times 10 \mathrm{~m}$. All trees larger than $15 \mathrm{~cm}$ in girth at breast height were tagged and mapped. We measured the height and diameter at breast height (DBH) in April 2006. The DBH was measured again in October 2007.

\section{Litterfall collection}

Litterfall was collected with $0.25 \mathrm{~m}^{2}$ circular traps. The traps consisted of a metallic hoop and nylon net and were positioned $1 \mathrm{~m}$ above the ground with plastic stakes. A total of 100 traps were placed in the plot, one in the center of each cell. Litterfall was collected at monthly intervals from August 2006 to August 2007. The samples were separated into C. japonica, broad-leaved trees and miscellaneous litter and then oven-dried at $70^{\circ} \mathrm{C}$ for 48 hours for measurement of dry mass. 
Data analysis

The above-ground dry mass $(\mathrm{Wt} ; \mathrm{kg})$ of an individual tree was the sum of mass of stem (Ws;kg), branches $(\mathrm{Wb} ; \mathrm{kg})$ and leaves $(\mathrm{Wl} ; \mathrm{kg})$ :

$$
\mathrm{Wt}=\mathrm{Ws}+\mathrm{Wb}+\mathrm{Wl} .
$$

The mass of each part of the individual tree (Wi) was estimated by the following allometric equation:

$$
\log (\mathrm{Wi})=\mathrm{a} \times \log (\mathrm{D})-\mathrm{b}
$$

where $\mathrm{D}$ is $\mathrm{DBH}(\mathrm{cm})$, and $\mathrm{a}$ and $\mathrm{b}$ are the coefficients whose values were obtained from Ando et al. (1968) for C. japonica and Ando et al., (1977) for broad-leaved trees (Table 2).

The aboveground biomass in each cell $\left(\mathrm{W}, \mathrm{kg} \mathrm{ha}^{-1}\right)$ was calculated as the sum of the biomass of all trees in the cell. The biomass increment was calculated as the difference in the biomass between 2006 and 2007. Above-ground net primary production, ANPP $\left(\mathrm{kg} \mathrm{ha}^{-1}\right.$ year $\left.^{-1}\right)$, was estimate by the summation method as

$$
\mathrm{ANPP}=\Delta \mathrm{Wt}+\Delta \mathrm{L}
$$

where $\Delta \mathrm{Wt}\left(\mathrm{kg} \mathrm{ha}^{-1} \mathrm{year}^{-1}\right)$ is biomass increment, and $\Delta \mathrm{L}$ is litterfall production $\left(\mathrm{kg} \mathrm{ha}^{-1} \mathrm{year}^{-1}\right)$. As an indicator of relative growth and production, we calculated the annual biomass increment, litterfall production and ANPP relative to aboveground biomass $\left(\Delta \mathrm{Wt}_{\mathrm{r}}, \Delta \mathrm{L}_{\mathrm{r}}\right.$ and $\mathrm{ANPP}_{\mathrm{r}}$, respectively, \%), as follows: 


$$
\Delta \mathrm{Wt}_{\mathrm{r}}=\Delta \mathrm{Wt} / \mathrm{W}
$$

$$
\Delta \mathrm{L}_{\mathrm{r}}=\Delta \mathrm{L} / \mathrm{W}
$$

$$
\mathrm{ANPP}_{\mathrm{r}}=\mathrm{ANPP} / \mathrm{W}
$$

The study plot was divided into three areas (ridge, mid-slope and valley) to compare aboveground biomass and productivity in relation to slope position (Fig. 1). We compared the Wt, $\Delta \mathrm{Wt}, \Delta \mathrm{L}, \mathrm{ANPP}, \Delta \mathrm{Wt}_{\mathrm{r}}, \Delta \mathrm{L}_{\mathrm{r}}$ and $\mathrm{ANPP}_{\mathrm{r}}$ among the three areas to infer the effects of slope position on stand productivity.

The microtopography of each of the 100 cells was evaluated by calculating the slope inclination and relief of each cell from the topographic survey data obtained by Inoue et al. (2008). The slope inclination and relief of each cell were calculated following methods described in Yamakura et al. (1995). The slope inclination (SI) was calculated based on the coefficients of the following linear equation of the regression plane obtained using coordinates of the four corners of each cell:

$$
\mathrm{Z}=\mathrm{b}_{0}+\mathrm{b}_{1} \mathrm{X}+\mathrm{b}_{2} \mathrm{Y} \text {, }
$$

where $\mathrm{Z}$ is the vertical elevation, and $\mathrm{X}$ and $\mathrm{Y}$ are the horizontal coordinates within the research plot (Fig 1). The $b_{0}, b_{1}$, and $b_{2}$ are coefficients obtained using linear least-squares regression.

SI was calculated as,

$$
\mathrm{SI}=\arccos \left(1 / \sqrt{b_{1}^{2}+b_{2}^{2}}\right) .
$$

The relief was evaluated using the index of convexity (IC), 


$$
\mathrm{IC}=\mathrm{Ec}-\mathrm{Es}
$$

where $\mathrm{Ec}$ is the mean elevation of the four corners of a given cell and Es is the mean elevation of the 12 outer corners of the surrounding eight cells. Larger SI indicates steeper slope. Positive IC indicates convex relief, whereas negative IC indcates concave relief. The mean and range of SI and IC in the study plot are shown in Table 3 . The slope and relief were relatively gentle on the ridge compared with the mid-slope and valley.

Path analysis, a kind of structural equation modeling (SEM) was used to infer the causal relationships among biomass, biomass increment, litterfall production, and microtopography. Path analysis, by way of correlation and partial regression coefficients, can be used to estimate direct and indirect contributions between the standardized predictor and criterion variables (Sokal and Rohlf 1995). We used the values obtained in each $10 \mathrm{~m} \times 10 \mathrm{~m}$ cell for the analysis $(\mathrm{n}=100)$. To infer the effect of microtopography on biomass and productivity, we hypothesized that the variation in biomass of $C$. japonica $(\mathrm{Bc})$ and broad-leaved trees $(\mathrm{Bb})$, biomass increment of $C$. japonica $(\mathrm{Gc})$ and broad-leaved trees $(\mathrm{Gb})$, and litterfall production of $C$. japonica $(\mathrm{Lc})$ and broad-leaved trees $(\mathrm{Lb})$ in each cell is caused by SI and IC. To infer competitive interactions between $C$. japonica and the broad-leaved trees, we hypothesized that $\mathrm{Bc}$ causes the variation among cells in $\mathrm{Bb}, \mathrm{Gc}, \mathrm{Lc}, \mathrm{Gb}$, and $\mathrm{Lb}$ and that $\mathrm{Bb}$ causes the variation among cells in $\mathrm{Gc}, \mathrm{Lc}, \mathrm{Gb}$, and $\mathrm{Lb}$. The fit of the hypothesized model was assessed using the maximum likelihood chi-squared statistic $\left(\chi^{2}\right)$ and non significant 
paths $(p>0.10)$ were eliminated to derive the best fit model to the observed data. The model fit was assessed using Akaike's information criterion (AIC). To investigate whether causal relationships varied among topographic types, separate models were fit for groups of cells in the ridge, mid-slope and valley positions, respectively. All path analyses were performed using the SPSS statistical package, AMOS 17.0 (SPSS Japan Inc., Tokyo).

\section{Results}

Total biomass of the study plot was $400.7 \mathrm{Mg} \mathrm{ha}^{-1}$, of which the broad-leaved trees contributed 93.4\% (Table 4). Biomass increment and litterfall production of $C$. japonica was markedly lower than those of the broad-leaved trees. Total biomass increment, litterfall production, and ANPP of the study plot were 11.5, 5.2 and $16.6 \mathrm{Mg} \mathrm{ha}^{-1} \mathrm{yr}^{-1}$, respectively, of which the broad-leaved trees contributed 96, 90 and $95 \%$, respectively.

Biomass $(\mathrm{Wt})$, biomass increment $(\Delta \mathrm{Wt})$, litterfall production $(\Delta \mathrm{L})$, and ANPP of the study plot decreased downslope from ridge to valley (Fig.2). The broad-leaved trees contributed to this trend, while the Wt, $\Delta \mathrm{Wt}, \Delta \mathrm{L}$, and ANPP of $C$. japonica did not vary with slope position. In contrast to the downslope decrease in $\mathrm{Wt}, \Delta \mathrm{Wt}, \Delta \mathrm{L}$, and $\mathrm{ANPP}$, relative biomass increment $\left(\Delta \mathrm{Wt}_{\mathrm{r}}\right)$ of the broad-leaved trees did not vary with slope position, and relative litterfall production $\left(\Delta \mathrm{L}_{\mathrm{r}}\right)$ and relative ANPP $\left(\mathrm{ANPP}_{\mathrm{r}}\right)$ increased downslope. The relative growth and production of $C$. japonica 
did not vary with slope position.

Effects of microtopography on stand structure and productivity

The results of path analysis showed a negative correlation between IC and SI (Fig. 3). IC had

positive effects on $\mathrm{Bb}$ and $\mathrm{Lb}$, and a negative effect on $\mathrm{Gc}$. Bc had positive effects on $\mathrm{Gc}$ and $\mathrm{Lc}$,

and a negative effect on $\mathrm{Lb}$. $\mathrm{Bb}$ had a positive effect on $\mathrm{Gb}$.

\section{Discussion}

The biomass of old-growth $C$. japonica plantations (77 to 126 years old) range, $210.5-515.0 \mathrm{Mg}$

ha $^{-1}$ (Tange et al. 1987, Nishimura et al. 1992, Watanabe and Mogi 2007). Although the biomass

of C. japonica in our study plot was only $26.5 \mathrm{Mg} \mathrm{ha}^{-1}$, the total biomass of $400.7 \mathrm{Mg} \mathrm{ha}^{-1}$ was

comparable to that of old-growth plantations, suggesting that the regenerated broad-leaved trees

complemented the decrease in $C$. japonica biomass. The total biomass was also comparable to that

of an old-growth warm-temperate laurel forest in southern Kyushu, Japan (323.4 $\mathrm{Mg} \mathrm{ha}^{-1}$,

Kimura 1960).

The broad-leaved trees contributed a substantial amount of the aboveground net primary

production (ANPP) of the study plot. More than $90 \%$ of the biomass increment and litterfall

production was attributed to the broad-leaved trees. The ANPP of the stand $\left(16.8 \mathrm{Mg} \mathrm{ha}^{-1} \mathrm{yr}^{-1}\right)$ was 
comparable to those of 11- to 49-year-old C. japonica plantations (8.9-16.7 $\mathrm{Mg} \mathrm{ha}^{-1} \mathrm{yr}^{-1}$, Tadaki et al. 1965) and that of the old growth warm-temperate laurel forest (21.6 $\mathrm{Mg} \mathrm{ha}^{-1} \mathrm{yr}^{-1}$, Kimura 1960). Aboveground biomass in the study plot decreased downslope. This is in contrast to several previous studies, which reported downslope increase in stand biomass in both plantations (Enoki et al. 1997, Tokuchi et al. 1999, Tsuji et al. 2007) and natural forest (Tateno et al. 2004). In our study plot, the slope inclination was relatively gentle and the relief was mild on the ridge. Relatively stable topographic conditions on the ridge may have promoted regeneration and establishment of the broad-leaved trees (Inoue et al. 2008). In contrast, unstable topographic conditions (steeper slope and concave relief) may have prohibited broad-leaved tree regeneration at lower slope positions.

Although biomass increment, litterfall production and ANPP of the broad-leaved trees decreased downslope, litterfall production and ANPP relative to the aboveground biomass increased downslope. The downslope increase in relative litterfall production suggested that trees on lower slope allocated their photosynthetic production more into leaves and branches, in part because of low stem density. The downslope increase in the relative production might be partly due to a gradient in nutrient and water availability along the slope. Nutrient availability generally increases downslope both in plantations (Hirobe et al. 1998; Tokuchi et al. 2000; Nishina et al. 2009) and natural forest (Vitousek et al. 2003; Porder et al. 2005; Takyu et al.2002; Tateno and Takeda 2003). In a cool 
temperate deciduous forest in Kyoto Prefecture, Japan, the downslope increase in ANPP was attributed to the increase in the rate of soil nitrogen mineralization (Tateno et al. 2004).

In addition to the gradient in nutrient and water availability along the slope, tree distribution may be another possible explanation for the downslope increase in relative production. The downslope decrease in tree density and above-ground biomass may have reduced the effects of neighborhood competition among trees. Various factors influence the relationships among biomass, production, and neighborhood competition, such as species, tree size, and disturbances (Uriarte et al. 2004). In our study plot, we observed that frequent ground disturbances at midslope, where the slope inclination was steepest resulted in accumulation of various rock and woody debris at lower slope positions. This may have prevented tree establishment and resulted in lower tree density and aboveground biomass downslope.

In the study plot, IC had a negative effect on Gc indicating that growth of $C$. japonica decreased with increasing convexity. Many studies have been reported that, near the upper part the slope, growth of $C$. japonica is low on convex topography where water and nutrient availability are low (Tange et al. 1989, Tokuchi et al. 1999). In contrast, IC had positive effects on $\mathrm{Bb}$ and $\mathrm{Lb}$ suggesting that the broad-leaved trees could establish and be productive on stable convex topography on and around the ridge of the study plot.

The lack of correlation between $\mathrm{Bc}$ and $\mathrm{Bb}$ suggested that $C$. japonica seemed to have no 
effect on the distribution of the broad-leaved trees. However, Bc had a negative effect on $\mathrm{Lb}$, indicating that the productivity of the broad-leaved trees decreased with increasing C. japonica biomass. This suggested a competitive relationship and/or spatial segregation between $C$. japonica and the broad-leaved trees. In $C$. japonica and broad-leaved mixed forests on Yakushima Island, the additive basal area of $C$. japonica increased stand-level litterfall production (Aiba et al. 2007). They proposed that the emergent status of $C$. japonica above the canopy of the broad-leaved trees contributed to additive basal area of mixed forests compared with broad-leaved forests. In the present study site, however, there was little difference in tree height between $C$. japonica and broad-leaved trees, suggesting that competitive interaction and/or spatial segregation may have resulted in the negative correlation between $\mathrm{Bc}$ and $\mathrm{Lb}$. We inferred that the lack of vertical stratification made the basal areas of two different crown forms exclusive rather than additive.

The results of our study suggested that in the unsuccessful, old-growth $C$. japonica plantation, variation in aboveground biomass might be determined by the distribution pattern of the naturally regenerated broad-leaved trees, which was largely affected by the topography. On the other hand, ANPP of the broad-leaved trees was affected by slope position and spatial distribution relative to the residual $C$. japonica trees, which may have resulted from competitive interaction or spatial segregation . 
Acknowledgment We would like to thank B. Kusumoto, K. Cho, K. Kaji, Y. Shiiba, K. Inoue, Osaki, Nagasawa of Kyushu University Forests for their assistance with fieldwork and for their helpful discussions. We also thank members of the Laboratory of Forest Resources, Kobe University for valuable comments on the study. This study was financially supported by Monitoring Sites 1000 Project of the Ministry of Environment, Japan. 


\section{Reference}

Aiba S, Hanya G, Tsujino R, Takyu M, Seino T, Kimura K, Kitayama K (2007) Comparative study of additive basal area of conifers in forest ecosystems along elevational gradients. Ecol Res 22: 439-450.

Ando T, Hatiya K, Doi K, Kataoka H, Kato Y, Sakaguchi K (1968) Studies on the system of density control of Sugi (Cryptomeria japonica) stand. Bull Gov For Exp Sta 209: 1-76 (In Japanese with English abstract)

Ando T, Chiba K, Nishimura T, Tanimoto T (1977) Temperate fir and hemlock forests in Shikoku. In: Shidei T, Kira T (eds) Primary productivity of Japanese forests, JIBP Synthesis 116. Univ Tokyo Press, Tokyo, pp213-245

Enoki T, Kawaguchi H, Iwatsubo G (1996) Topographic variations of soil properties and stand structure in a Pinus thunergii plantation. Ecol Res 11:299-309

Enoki T, Kawaguchi H, Iwatsubo G (1997) Nutrient-uptake and nutrient-use efficiency of Pinus thunbergii Parl. along a topographical gradient of soil nutrient availability. Ecol Res 12: 191-199

Gower ST, McMurtrie, Murty D (1996) Aboveground net primary production decline with stand age: potential causes Trends Ecol Evol 11: 378-

Hasegawa M, Taira H (2000) The characteristics of species composition of the hardwoods on 
Cryptomeria japonica plantation in heavy snow regions. J Jpn For Soc 82: 28-33 (In Japanese with English abstract)

Hirobe M, Tokuchi N, Iwatsubo G (1998) Spatial variability of soil nitrogen transformation patterns along a forest slope in a Cryptomeria japonica D. Don plantation. Eur J Soil Biol 34: $123-131$

Ichikawa T, Takahashi T, Asano Y (2006) Comparison of changes in organic matter dynamics due to stand age between artificial Japanese ceder (Cryptomeria japonica D. Don) forests and Japanese Cypress (Chamaecyparis obtussa Sieb. Et Zucc.) forests. J Jpn For Soc 88: 525-533 (In Japanese with English abstract)

Imada M, Masutani T, Yamamoto K, Teraoka Y (1991) Cometition between planted Sugi (Cryptomeria japonica) and natural broad-leaved trees in mixed stands in mountainous regions of Kyushu. Sci Bull Fac Agr Kyushu Univ 46: 93-102 (In Japanese with English abstract)

Inagaki Y, Miura S, Kohzu A (2004) Effects of forest type and stand age on litterfall quality and soil N dynamics in Shikoku district, southern Japan. For Ecol Man 202: 107-117

Inoue T, Enoki T, Tashiro N, Sakuta K, Inoue S (2008) Effects of topography and planted trees on the distribution of naturally regenerated broad-leaved trees in a 140-year-old Cryptomeria japonica plantation in northern Kyushu, Japan. J For Res 13:365-371 
Ito S, Nakagawa M, Buckley GP, Nogami K (2003) Species richness in sugi (Cryptomeria japonica D. Don) plantation in southeastern Kyushu, Japan: the effects of stand type and age on understory trees and shrubs. J For Res 8:49-57

Ito S, Ishigami S, Mitsuda Y, Buckley GP (2006) Factors affecting the occurrence of woody plants in understory of sugi (Cryptomeria japonica D. Don) plantations in a warm-temperate region in Japan. J For Res 11:243-251

Kimura M (1960) Primary production of the warm-temperate laurel forest in the southern part of Oosumi Peninsula, Kyushu, Japan. Misc Rep Res Inst Nat Reso 52/53: 36-47

Kira T, Shidei T (1967) Primary production and turnover of organic matter in different forest ecosystems of the western Pacific. Jpn J Ecol 17: 70-87

Kodani J (2006) Species diversity of broad-leaved trees in Cryptomeria japonica plantations in relation to the distance from adjacent broad-leaved forests. J For Res 11: 267-274

Kohama T, Mizoue N, Ito S, Inoue A, Sakuta K, Okada H (2006) Effects of light and microsite conditions on tree size of 6-year-old Cryptomeria japonica planted in a group selection opening. J For Res 11:235-242

Kominami Y, Saito S, Nagamatsu D, Tanohchi H, Sato T (2004) Structutal changes of tree population in unsuccessful Cryptomeria japonica plantations in central high land of 
Kyushu. Kyushu J For Res 57:87-93 (In Japanese with English abstract)

Kondo H, Noda I, Hori Y, ImadaM, Yoshida S (2001) The growth process of the old-age Hinoki(Chamecyparis obtuse) at Tatsutayama Experiment forest. Bull Kyushu Jpn For Soc 37-40 (In Japanese)

Luyssaert S, Schulze ED Borner A, Knohl A, Hessenmoller D, Law BE, Ciais P, Grace J (2008) Old-growth forests as global carbon sinks. Nature 455: 213-215

Masaki T, Ohta T, Sugita H, Oohara H, Otani T, Nagaike T, Nakamura S (2004) Structure and dynamics of tree populations within unsuccessful conifer plantations near the Shirakami Mountains, a snowy region of Japan. For Ecol Manag 194:389-401

Masaki T, Mori S, Kajimoto T, Hitsuma G, Sawata S, Mori M, Osumi K, Sakurai S, Seki T (2006) Long-term growth analyses of Japanese cedar trees in a plantation: neighborhood competition and persistence of initial growth deviations. J For Res 11:217-225

Midgley JJ, Parker R, Laurie H, Seydack A (2002) Competition among canopy trees in indigenous forests: an analysis of the 'additive basal area' phenomenon. Aust Ecol 27: 269-272

Nishina K, Takenaka C, Ishizuka S (2009) Spatial variations in nitrous oxide and nitric oxide emission potential on a slope of Japanese ceder (Cryptomeria japonica) forest. Soil Sci Plant Nut 55: 179-189

Nishimura T, Yoshikawa K, Ikemoto A, Nagamori M (1992) Biomass and growth of old 
Cryptomeria japonica plantations. (1) 80-year-old stand in Kochi Okuminakawayama National Forest. Bull Kochi Univ For 19: 73-81

Porder S, Payton A, Vitousek PM (2005) Erosion and landscape development affect plant nutrient status in the Hawaiian Islands. Oecologia 142: 440-449

Ryan MG, Binkley D, Fownes JH, Giardina CP, Senock RS (2004) An experimental test of the causes of forest growth decline with stand age. Ecol Monog 74: 393-414

Sato T, Tanouchi H, Kominami Y (1995) Stand structure and emergent mechanism of poor conifer plantations in Kyushu backbone mountain range. Bull Kyushu Jpn For Soc 48: 67-68 (In Japanese)

Shutou K, Nakane K (2004) Changes in soil carbon cycling for stand development of Japanese ceder (Cryptomeria japonica) plantations following clear-cutting. Ecol Res 19: 233-244

Sokal R, Rohlf J (1995) Biometry: the principles and practice of statistics in biological research. $3^{\text {rd }}$ edition. W.H.Freeman and Co., San Francisco, California 859p.

Tadaki Y, Ogata N, Nagatomo (1965) The dry matter productivity in several stands of Cryptomeria japonica in Kyushu. Bull For For Prod Res Inst 173: 45-66 (In Japanese with English abstract)

Takeuchi I (2005) The growth of diameters and stand stem volumes in old man-made Sugi (Cryptomeria japonica) stands. J Jpn For Soc 87: 394-401 (In Japanese with English 
abstract)

Takyu M, Aiba S, Kitayama K (2002) Effects of topography on tropical lower montane forests under different geological conditions on Mount Kinabalu, Borneo. Plant Ecol 159:35-49

Tange T, Yamanaka I, Suzuki M (1987) Growth and biomass of an old manmade Cryptomeira japonica stand. Misc Inform Tokyo Univ For 25:243-259 (In Japanese with English abstract)

Tange T, Matsumoto Y, Masimo Y, Sakura T (1989) Height growth of Cryptomeria japonica trees planted on a slope - Comparison among the near ridge, the mid-slope and the near bottom in the Tokyo University Forest in Chiba -. Bull Tokyo Univ For 81: 39-51 (In Japanese with English abstract)

Tateno R, Takeda H (2003) Forest structure and tree species distribution in relation to topography-mediated heterogeneity of soil nitrogen and light at the forest floor. Ecol Res $18: 559-571$

Tateno R, Hishi T, Takeda H (2004) Above- and belowground biomass and net primary production in a cool-temperate deciduous forest in relation to topographical changes in soil nitrogen. For Ecol Man 193: 297-306

Tokuchi N, Takeda H, Yoshida K, Iwatsubo G (1999) Topographical variations in a plant-soil system along a slope on Mt Ryuoh, Japan. Ecol Res 14: 361-369 
Tokuchi N, Hirobe M, Koba K (2000) topographical differences in soil N transformation using 15N dilution method along a slope in a conifer plantation forest in Japan. J For Res 5: 13-19

Tsuji T, Ishii H, Kanazawa Y (2007) The relationship between slope position and stand structure of an old Chamaecyparis obtuse plantation in northern Kyoto prefecture, Japan. J Jpn For Soc 89: 160-166 (In Japanese with English abstract)

Uriatre M, Condit R, Canham CD, Hubbell SP (2004) A spatially explicit model of sapling growth in a tropical forest: does the identity of neighbours matter? J Ecol 92: 348-360

Vitousek PM, Chadwick O, Matson P, Allison S, Derry L, Kettley L, Luers A, Mecking E, Monastra V, Porder S (2003) Erosion and rejuvenation of weathering-derived nutrient supply in an old tropical landscape. Ecosystems 6: 762-772

Watanabe H, Mogi Y (2007) Growth and biomass of a 92-year-old Cryptomeria japonica plantation. Bull Gifu Pref Res Ins For 36: 1-7. (The original Japanese title was translated tentatively into English by the authors of the paper)

Yamakura T, Kanzaki M, Itoh A, Ohkubo T, Ogino K, Chai EOK, Lee HS, Ashton PS (1995) Topography of large-scale research plot established within a tropical rain forest at Lambir Sarawak. Tropics 5:41-56

Yokoi S, Yamaguchi K (2000) Treatment of unsuccessful Cryptomeria japonica plantations in the snowy region: Management plan from the viewpoint of the height growth process of 
Cryptomeria japonica and broad-leaved trees. Jpn J For Environment 42: 1-7 (In

Japanese with English abstract) 
Figure legends

Fig. 1 Topographic map of the study plot $(100 \times 100 \mathrm{~m})$ indicating the classification of each cell $(10 \times 10 \mathrm{~m})$ by slope position.

Fig. 2 Biomass, biomass increment, litterfall production and aboveground net primary production (ANPP) of Criptomeria japonica (filled bars) and broad-leaved trees (open bars) in ridge, slope and valley slope positions. Biomass increment, litterfall production and ANPP relative to the aboveground biomass (\%) are shown as black and white circles for $C$. japonica and broad-leaved trees, respectively.

Fig. 3 A path diagram of the relationships among index of convexity (IC), slope inclination (SI), biomass of Cryptomeria japnica $(B c)$ and broad-leaved trees $(B b)$, biomass increment of $C$. japponica $(G c)$ and broad-leaved trees $(G b)$, and litterfall production of $C$. japonica $(L c)$ and broad-leaved trees $(L b)$ obtained for each slope position: a) ridge, b) mid-slope, c) valley. All path coefficients represent standardized partial regression coefficients. ${ }^{*} P<0.05$, ${ }^{* *} P<0.01$, $* * * P<0.001$ 
Table 1 Tree density $\left(\right.$ stems ha $\left.{ }^{-1}\right)$, basal area $\left(\mathrm{m}^{2} \mathrm{ha}^{-1}\right)$ and maximum tree height $(\mathrm{m})$ of each species with stem girth larger than $15 \mathrm{~cm}$ in the study plot.

\begin{tabular}{lccr}
\hline Species & $\begin{array}{c}\text { Tree } \\
\text { density } \\
\left(\text { stems ha }{ }^{-1}\right)\end{array}$ & $\begin{array}{c}\text { Basal area } \\
\left(\mathrm{m}^{2} \mathrm{ha}^{-1}\right)\end{array}$ & $\begin{array}{r}\text { Maximum tree } \\
\text { height }(\mathrm{m})\end{array}$ \\
\hline Cryptomeria japonica D. Don & 46 & 7.4 & 26.8 \\
Quercus salicina Blume & 90 & 8.6 & 18.4 \\
Carpinus tschonoskii Bl. & 66 & 7.0 & 14.7 \\
Camellia japonica L. & 474 & 4.4 & 9.7 \\
Quercus acuta Thunb. ex Murray & 22 & 4.2 & 14.3 \\
Cinnamomum japonicum Sieb. ex Nakai & 139 & 4.1 & 13.5 \\
Swida controversa Sojak & 23 & 3.9 & 20.5 \\
Machilus thunbergii Sieb. Et Zucc & 29 & 2.2 & 14.5 \\
Diospyros japonica Sieb. et Zucc. & 17 & 1.3 & 17.1 \\
Acer palmatum Tunb. & 15 & 1.1 & 16.2 \\
Machilus japonica Sieb. et Zucc. & 46 & 1.0 & 12.1 \\
Others & 352 & 6.8 & 20.3 \\
& & & \\
Total & 1319 & 52.0 & 26.8 \\
\hline
\end{tabular}

Data are from Inoue et al. 2008. 
Table 2 Parameters applied to calculation for the biomass of Cryptomeria japonica and broad-leaved trees by the following allometric equations: $\log ($ Wi $)=a \times \log (\mathrm{D})-\mathrm{b}$, where $\mathrm{D}$ is DBH $(\mathrm{cm})$, and $\mathrm{a}$ and $\mathrm{b}$ are the coefficients dependent on the species and the part of the trees. The weight of each part of the individual tree (Wi: $\mathrm{kg}$ ) was weight of stem (Ws), branch (Wb) and leaf (Wl), respectively. The values of a and b are from Ando et al. (1968) for C. japonica and Ando et al., (1977) for broad-leaved trees.

\begin{tabular}{lccc}
\hline Trees & Part & $\mathrm{a}$ & $\mathrm{b}$ \\
\hline \multirow{3}{*}{ Cryptomeria japnica } & $\mathrm{Ws}$ & 2.3478 & 1.2406 \\
& $\mathrm{~Wb}$ & 1.5945 & -0.9894 \\
& $\mathrm{Wl}$ & 1.0963 & -0.1329 \\
& & & \\
Broad-leaved trees & $\mathrm{Ws}$ & 2.5857 & -1.2268 \\
& $\mathrm{~Wb}$ & 2.6560 & -1.8546 \\
& $\mathrm{Wl}$ & 1.7433 & -1.6735 \\
\hline
\end{tabular}


Table 3 Mean and range (minimum - maximum) of index of convexity (IC) and slope inclination (SI) for each slope position.

\begin{tabular}{lccc}
\hline & Ridge & Mid-slope & Valley \\
\hline IC $(\mathrm{m})$ & 2.3 & 0.3 & -4.4 \\
& $(-1.4-4.9)$ & $(-3.2-2.9)$ & $(-6.7--2.7)$ \\
SI (degree) & 28.4 & 40.2 & 37.0 \\
& $(17.1-39.2)$ & $(17.7-50.2)$ & $(26.7-50.4)$ \\
\hline
\end{tabular}

Data are from Inoue et al. 2008. 
Table 4 Biomass, biomass increment, litterfall mass and aboveground net primary production (ANPP) of Cryptomeria japonica (CJ) and broad-leaved trees (BL) in the study plot. The relative values of biomass increment, litterfall and ANPP per unit biomass (\%) are given in the parentheses.

\begin{tabular}{lccc}
\hline & CJ & BL & Total \\
\hline $\begin{array}{l}\text { Biomass } \\
\left(\mathrm{Mg} \mathrm{ha}^{-1}\right)\end{array}$ & 26.5 & 374.2 & 400.7 \\
& & & \\
$\begin{array}{l}\text { Biomass increment } \\
\left(\mathrm{Mg} \mathrm{ha}^{-1} \mathrm{yr}^{-1}\right)\end{array}$ & 0.49 & 11.0 & 11.5 \\
& $(0.57)$ & $(3.88)$ & $(3.30)$ \\
$\begin{array}{l}\text { Litterfall } \\
\left(\mathrm{Mg} \mathrm{ha}^{-1} \mathrm{yr}^{-1}\right)\end{array}$ & 0.45 & 4.7 & 5.2 \\
& $(0.37)$ & $(5.08)$ & $(8.04)$ \\
$\mathrm{ANPP}^{-1}$ & 0.94 & 15.7 & 16.6 \\
$\left.\mathrm{Mg} \mathrm{ha}^{-1} \mathrm{yr}^{-1}\right)$ & $(0.95)$ & $(8.99)$ & $(7.48)$ \\
& & & \\
\hline
\end{tabular}


Enoki et al. Fig. 1

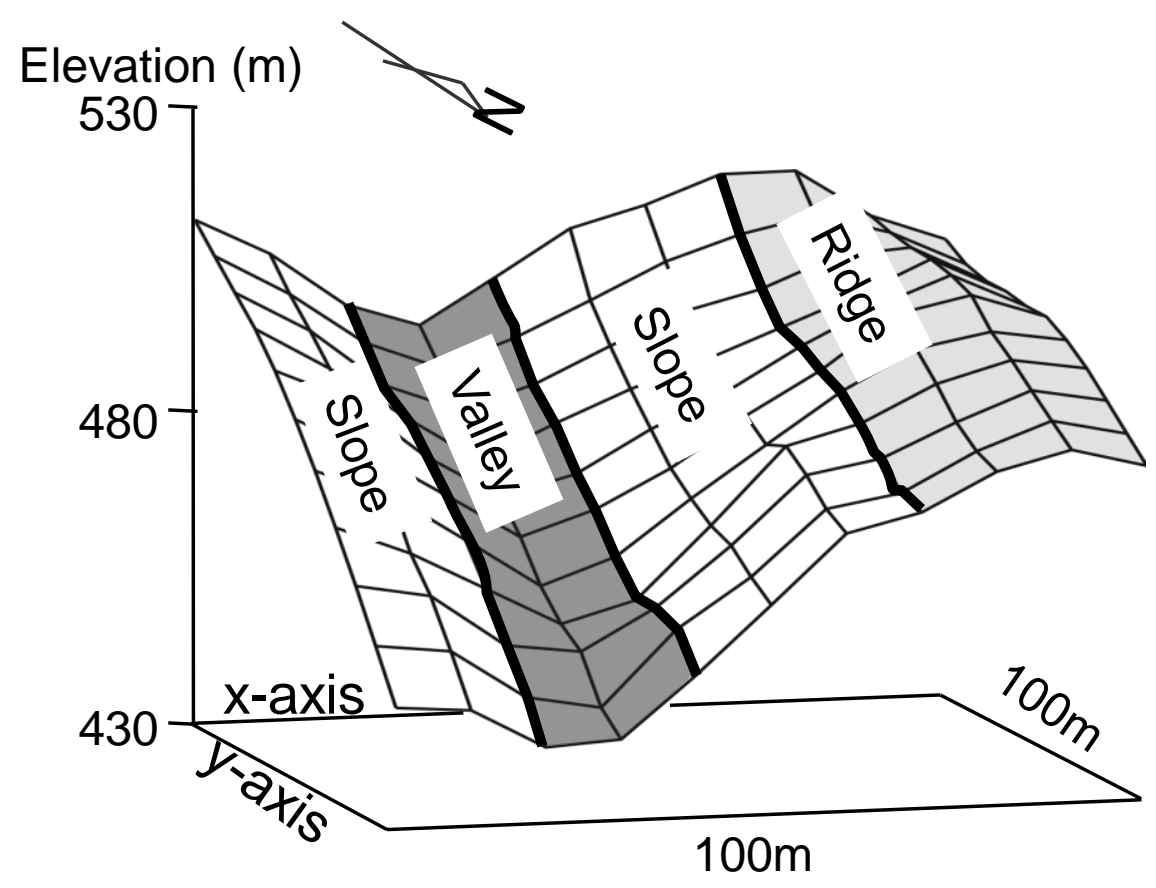


Enoki et al. Fig. 2

Enoki et al. Fig. 3

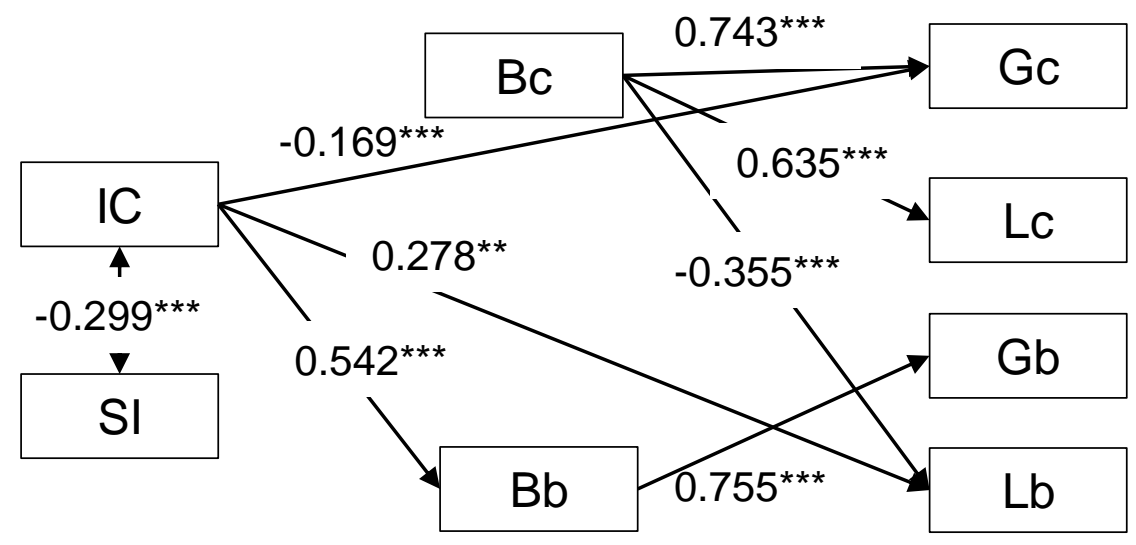

